DOI: https://doi.org/10.32841/2413-2675/2020-45-15

Budiakova Olena
Candidate of Economic Sciences,
Senior Instructor at Department of Business Economics and Tourism,
Kyiv National University of Technology and Design

Будякова О.Ю.

Київський національний університет технологій та дизайну

Zadorozhnyi Vladyslav

Master at the Department of Business Economics and Tourism, Kyiv National University of Technology and Design

Задорожний B.B.

Київський національний університет технологій та дизайну

\title{
ORGANIZATION OF FOREIGN ECONOMIC ACTIVITY DEVELOPMENT AT THE ENTERPRISE
}

\section{ОРГАНІЗАЦІЯ РОЗВИТКУ ЗОВНІШНЬОЕКОНОМІЧНОЇ ДІЯЛЬНОСТІ НА ПІДПРИЄМСТВІ}

\begin{abstract}
Summary. In this article, it was established that the organization of FEA development at the enterprise is one of the main elements that helps to qualitatively establish the enterprise's activities in foreign markets. It is determined that each interpretation of the FEA is an addition to the previous ones. The structure of formation of FEA at the enterprise was investigated. The main key elements that allow successful implementation of FEA are considered. The reasons that force entrepreneurs to introduce FEA were analyzed. The main directions of economic activity in all countries of the world were investigated. The analysis of FEA was carried out, recommendations were made on the effectiveness of the implementation and conduct of foreign economic activities. The issue of FEA is extremely relevant and requires detailed study.
\end{abstract}

Keywords: foreign economic activity, economy, profit, management, personnel, efficiency, resources.

Problem setting. In our time, the economy is developing quite rapidly, and its effectiveness depends primarily on the successful introduction of scientific and technical potential, the creation of conditions for its successful implementation, the number of own patents and scientific developments, as well as the state's interest in the development of the latest technologies. Implementation of an effective FEA system. The introduction of an effective FEA system determines the emergence of competitive advantages, which is realized thanks to the measures that were used in the process of implementing FEA. In the context of the modern development of the economy, FEA acts as an important component in the formation of foreign relations, contributes to strengthening the position of the enterprise in the international arena and its resistance to environmental changes. All modern achievements of science, namely scientific and technological progress, active development of nanotechnologies, introduction of new economic and socio-political concepts, all this has an immense impact on production, domestic and foreign policy of any enterprise.
But the following issues have not yet been resolved: the efficiency of using FEA at the enterprise; rational structure of FEA units; effective management of the company's foreign economic activity.

Analysis of recent publications on the problem. The foreign economic activity of the enterprise is the subject of many studies by domestic and foreign authors. Issues of development of foreign economic activity, problems of access of enterprises to international markets are described in the works of Velichko O.G. [1], Guzenko G.M. [2]. Study of FEA as a modern economic phenomenon, research on the effectiveness of the FEA, the conditions for its successful implementation was carried out in the works of Kozak Y.G., Longvinova N.S., Guzenko G.M. in a fairly complete review [3] determine the current state and promising areas of research in foreign economic activity, focusing on issues that model foreign economic policy in terms of the following concepts: competitiveness, international markets, economic development [3], the function of gaining, fixing and profitability of external consumers, and at the second stage of considering the issues of foreign trade, focuses on the following factors - the value of foreign economic activity as a function of additional stimulation of sales, strengthening competitiveness, growth rate of the enterprise. Kozak Y.G. and Zayats M.A. analyze "the most popular and promising instruments of foreign economic activity" and also place great emphasis on an attempt to define the concept of foreign economic activity based on the modern state of development of the economy of Ukraine and the world [3]. Longvinova N.S. [3] studies the role of foreign economic channels in the distribution economy (sharing economy), focusing on the main problem of this work - how foreign economic activity affects the economic development of the state. In general, studies of foreign economic activity refer to issues that are tangential to the implementation of plans for enterprises to enter the international arena at the level of the organization of foreign economic activity as a separate link or governing body. Analysis of external economic systems in the context of the process of adaptation of the enterprise in the works of Melnik A.O [4; 5]. Melnik A.O. also emphasizes in 
scientific research the theoretical basis for the functioning of foreign economic systems. Among the works of domestic scientists, it is worth noting the study of Gayduchenko Y.O. [2], Momot Y.G. [1], regarding the functions of foreign economic activity at the international level of the enterprise's activity. Despite a significant number of studies of foreign economic activity, the analysis of publications confirms the insufficient elaboration of a systemic point of view on issues related to the influence of foreign economic activity on the enterprise, when applying mechanisms for entering international markets. This study allows you to systematize and generalize the place of foreign economic activity in the socio-economic system.

Unresolved part of the study. Looking at today's realities, and a sufficient number of studies and innovative projects in the field of foreign economic relations are not defined by a single strategy and approach to the comprehensive description and classification of foreign economic activity of the enterprise. The world is developing rapidly, and many issues are now debatable. Foreign economic activity requires more detailed study, since it is the driving force for ensuring the profitability of the enterprise and its capabilities in foreign markets.

The purpose of the study is to consider the following terms and concepts as: foreign economic activity, foreign markets, competitiveness, profitability of the enterprise, personnel management, personnel policy, corporate culture of the enterprise, identification of an innovative component in the process of introducing foreign economic activity of the enterprise.

Presentation and justification of the main results. Exploring the realities of today, when globalization processes are increasingly developing and affecting international economic relations, an important issue is the study of foreign economic activity [4, p. 110].

This issue is important both for Ukraine as a whole and for individual enterprises, since foreign economic activity actively helps to successfully make managerial decisions on the way to foreign markets, especially when Ukraine is now on the way to the European Union [5, p. 31].

Considering FEA as an economic concept, an important element is that each of its subjects is guided by the principle of economic freedom, that is, he can, at his discretion, be a member of foreign economic relations, operate these relations of his own free will, based on the norms defined by the legislation of Ukraine [6].

Foreign economic activity is carried out on the basis of established rules and norms contained in the law on foreign economic activity and other acts [7].

The second important aspect when considering foreign economic activity, I consider it necessary to emphasize the following concepts, which are characteristic of foreign economic activity. They are schematically shown in Figure 2.

The enterprise is the main component of foreign economic activity. An enterprise can provide services, produce goods for both its own profit and meet the needs of consumers [8, p. 207].

The modern international division of labour offers great opportunities for obtaining economic preferences.

For example, when producing goods in their own country, having numerous capacities and opportunities to produce this goods in large quantities, sometimes the problem of not being able to sell it due to lack of interest of consumers may arise.

So a product that is produced in one State can not be sold to its own population, but with phenomenal success break into the market of neighboring States, or States with a lower level of development.

This is what specialists in foreign economic relations are doing, looking for opportunities to enter international markets with the greatest benefit and minimum risks for the enterprise [9, p. 136].

Rapid changes in the economy of Ukraine place new requirements on the professional qualifications of personnel and require new modern strategies for managing personnel of enterprises. The availability of only the necessary competencies no longer meets the requirements of modern enterprises. Employees are required to respond quickly, adaptively, loyalty and mobility, to be ready to be responsible for delegated authority and additional burdens, to constantly strive for professional growth, to improve both personal and business qualities [10, p. 176].

Modern strategies for personnel management in terms of personnel selection, recruitment, development and evaluation will allow the enterprise to adequately respond to environmental changes, and therefore increase its competitiveness and efficiency [11, p. 235].

To date, there is no single classification of HR strategy. Some scientists do not consider it necessary to classify personnel strategies and present them in a set of measures for strategic management of

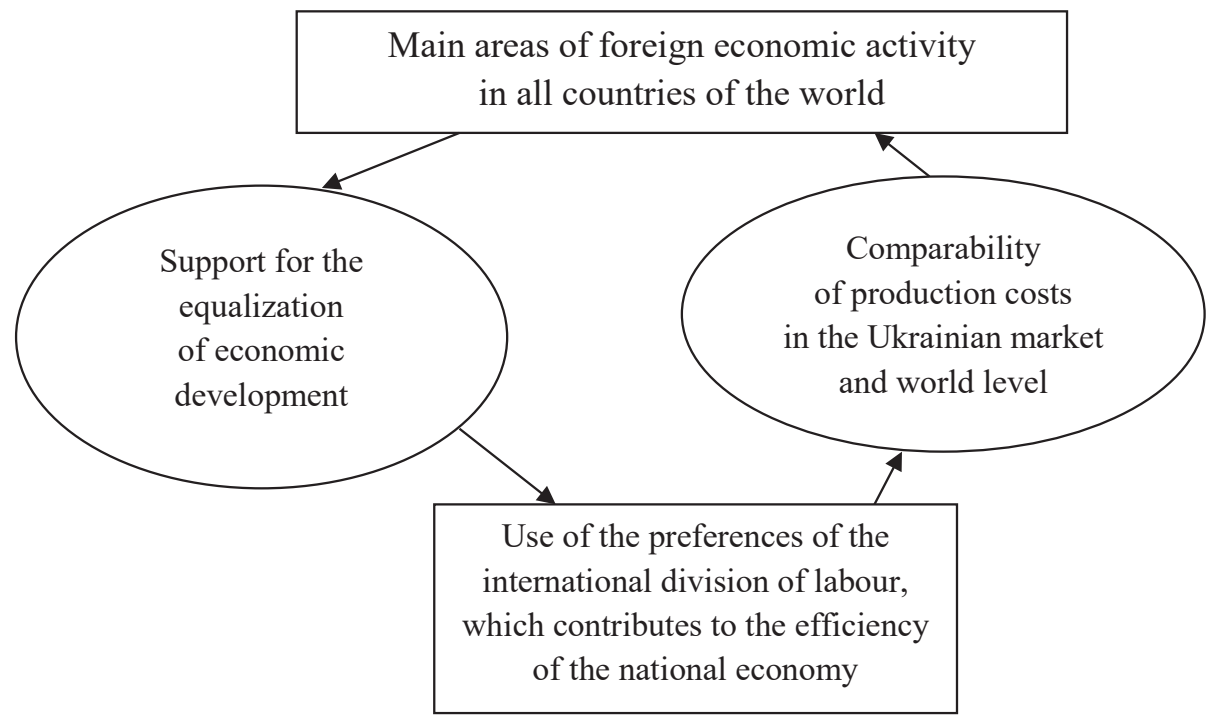

Figure 1. Main areas of foreign economic activity in all countries of the world 


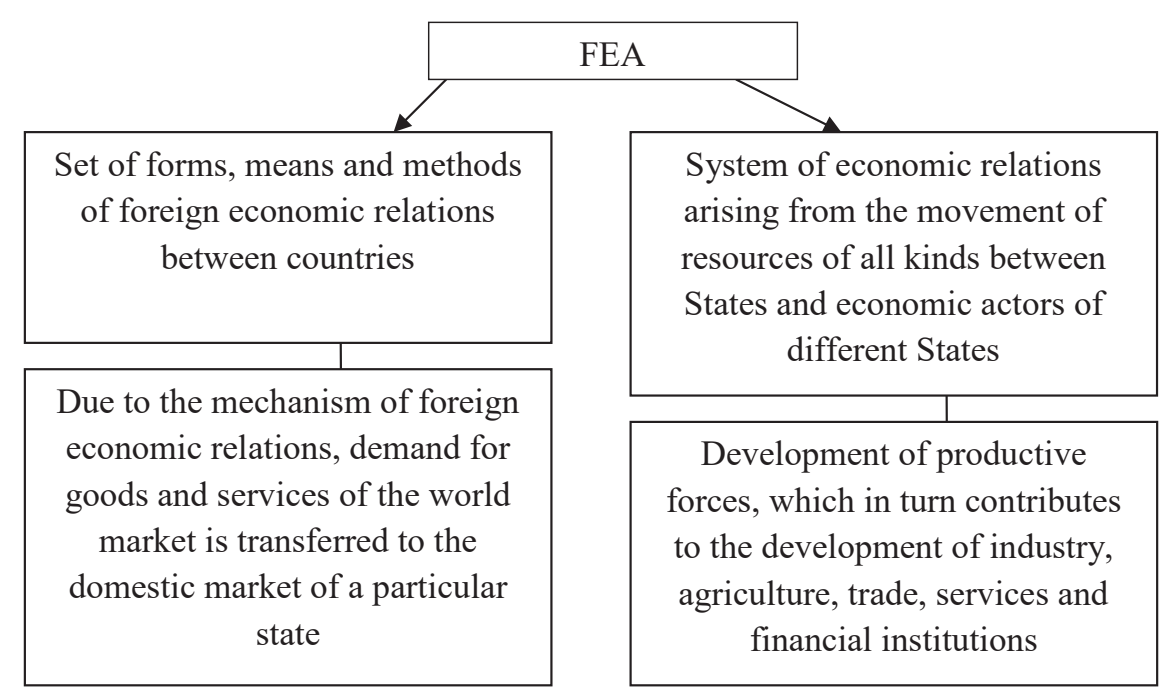

Figure 2. Basic factor, or characteristic of FEA

Source: compiled by the authors

enterprise personnel. While others note the existence of certain types of personnel management strategies and provide appropriate classifications. Of course, the choice of a certain type or types of personnel management strategies should be consistent with the enterprise development strategies, which, in turn, requires employees to have the appropriate knowledge, skills, experience, the necessary level of competence, a system of values, that is, a certain set of qualities that will ensure the achievement of the main mission and goals of enterprise development. To determine the direction and basis of work with personnel, general and specific requirements for them, a personnel policy of the organization is being developed. It implements the goals and objectives of human resources management [12, p. 43].

The innovative nature of the activity of the modern personnel policy of the enterprise, the priority of issues of service quality change the requirements for the employee, increase the importance of creative attitude to work, high professionalism and creativity. This has already led to significant changes in the principles, methods and socio-psychological issues of personnel management [13, p. 12].

The reasons that force entrepreneurs to introduce FEA are depicted in Figure 3.

Recently, in the scientific literature, it is increasingly possible to encounter the concept of an foreign trade company (hereinafterFTC). Here are the definitions and main goals of creating the FTC.
FTC in the context of an economic unit is an independent part of an enterprise or institution, but is not a legal entity. The FTC is headed by the deputy director of the enterprise, or the deputy general director for FEA, if such a position is provided for by the enterprise management structure.

The goals of creating the FTC are:

- implementation of planned export and import volumes at the enterprise, improvement of product quality, technological process efficiency;

- increasing the efficiency of export products sales, work to improve the nomenclature, organization of technical maintenance of products outside the country of manufacture;

- smart enterprise policies that enable more rational use of own resources;

- finding the best ways to sell products on the market;

- scientific cooperation with foreign partners to introduce the latest technologies into their own production process.

If the enterprise plans to conduct active foreign economic activity, then the head of the department of foreign economic activity is the main person responsible for the implementation of foreign economic activity at this enterprise.

The head of the FEA is respectively subordinate to:

- sector responsible for carrying out commercial work;

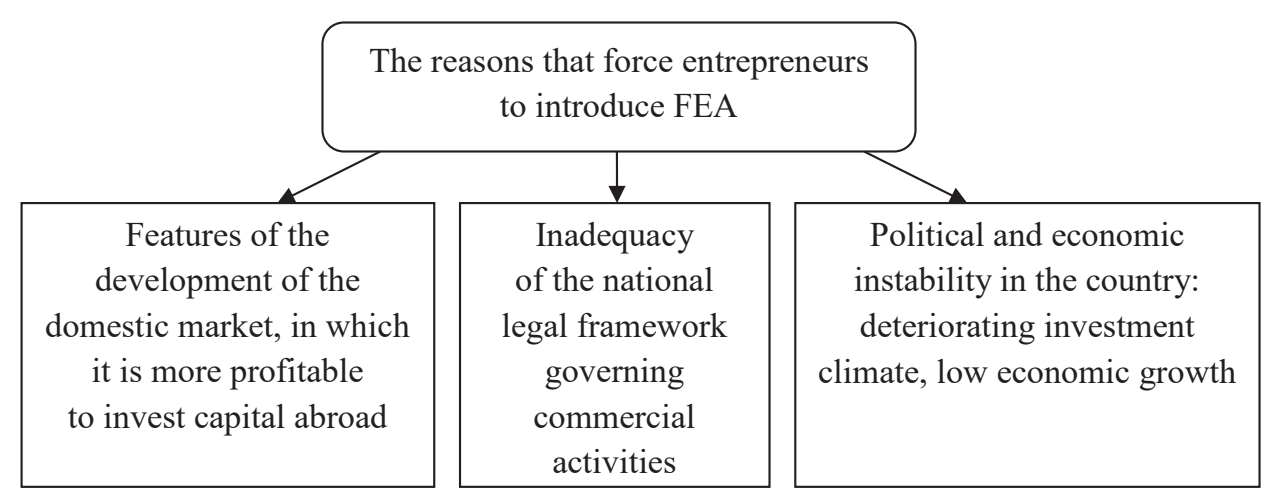

Figure 3. The main reasons for the introduction FEA in the enterprise 
- the sector responsible for the implementation of the economic programme;

- marketing sector;

- engineering and Technical Branch;

- protocol group of the enterprise.

Directions to improve the implementation of FEA at the enterprise:

1. Clear management of export activities. It is meant to constantly control and monitor all processes in the enterprise that are directly related to the export of products. Such activities include: writing a business plan [14, p. 47], monitoring its compliance, introducing a strategy and corporate culture establishing a unified system for controlling export activities [15, p. 87].

2. Accounting and auditing. Counting and erecting all available and used resources will provide more opportunities to search, and make better use of the enterprise's own and borrowed reserves, which can significantly affect production capacity.

3. Resource management. An important aspect in the process of implementing FEA. It helps to accumulate, find, calculate the use of all available resources in time to continue their rational use without downtime in warehouses.

4. Consumer demand and its valuation. One of the decisive steps for the success of the implementation of FEA. It provides an analysis of the volumes of the future circle of consumers according to various international standards, in accordance with the type of products produced by the enterprise. It is on the correctness of the calculations that the intensity of the enterprise strategy depends.

5. Export activity of the enterprise and its valuation. It is necessary to calculate the most profitable quantity of the item to be exported. It is a good tool for monitoring and studying the market of other states, implementing the preparatory plan for the export of products.

So, summing up the research, it can be concluded that at this stage of human development, FEA is a very important part in the management of any enterprise, since it fulfills the main tasks that arise when the enterprise decides to concentrate its own activities not only within the country, but also to enter the international arena.

In order to make a FEA at the enterprise, the following recommendations should be followed more effectively:

1. Pay as much attention as possible to foreign markets.

2. Actively participate in foreign activities, increase its own export potential.

3. Monitor and monitor competitors to minimize risks when entering foreign markets.

4. Maintain close economic ties with foreign enterprises - partners.

5. Introduce measures that will help reduce the cost of their own products for export.

6. Accumulate, and allocate as much resources as possible to study international consumer demand and increase productivity.

7. Control business activities, which significantly affects the effectiveness of the chosen strategy in entering foreign markets.

8. The creation of a separate division of FEA, headed by a responsible executive, will provide more opportunities for control and more rational management of foreign economic activity.

9. Establish an analytical monitoring department that will deal with miscalculations and provide advice on current issues and timely ways to address them.

Conclusions and prospects for further research. In today's economic environment, in view of the ever-changing economic situation in the world, in order to increase their own efficiency, enterprises need to pay attention to foreign economic activity, which allows them to develop an effective system for entering foreign markets, taking into account various factors of influence on the enterprise.
High-quality personnel selection is also necessary, since labor productivity is the main indicator of the enterprise's production capacity. If it is necessary to reduce staff, which is most relevant in the context of the world pandemic associated with the spread of the virus COVID-19 it is necessary to take into account the professional qualities of workers who are planned to be left. They must work out more and give the same power.

It is recommended to implement an anti-crisis system, constantly analyze the internal and external environment, monitor risks, and create forecasts to prevent crisis situations in the future. It is worth creating a system of indicators that will allow you to efficiently and quickly analyze the current state of the enterprise, development goals and prospects for the future, create an effective development strategy based on the data of your own enterprise control system.

\section{References:}

1. Velichko O.G. (2010) Menedzhment zovnishnoekonomichnoi diialnosti [Management of foreign economic activity]. Dnipropetrovsk: NMetAU. (in Ukrainian)

2. Guzenko G.M., Gaiduchenko Y.O. (2013) Zovnish 'oekonomichna dijal'nist pidpryjemsta: sutnist', ekonomichnyi mechanyzm ji rozbydovy, osoblyvosti [Foreign economic activity of the enterprise: essence, economic mechanism of its development, peculiarities]. Bulletin of the National University "Law Academy of Ukraine named after Yaroslav Mudryi, vol. 3, pp. 15-23.

3. Kozak Y.G., Longvinova N.S., Zayets M.A. (2012) Zovnishnoekonomichna diialnist pidpryiemstv [Foreign economic activity of enterprises], vol. 4. Kyiv: «Osvita Ukrajiny». (in Ukrainian)

4. Melnik A.O. (2014) Svitovi ekonomichni kryzy v ekonomici Ukrajiny ta jikh naslidky [World economic crises in the economy of Ukraine and their consequences]. Global and national economic problems, vol. 2, pp. 108-113.

5. Melnik A.O. (2012) Adaptacija vitchyznjanykh pidpryjemstv v umovakh svitovoji ekonomichnoji kryzy [Adaptation of domestic enterprises in the conditions of the world economic crisis]. Business-Inform, vol. 12, pp. 30-32.

6. Law of Ukraine on Foreign Economic Activity (Vedomosti of the Supreme Council of the Ukrainian SSR (RT)), 1991, no. 29, p. 377. URL: https://zakon.rada.gov.ua/laws/show/959-12 (accessed 15 August 2020). (in Ukrainian)

7. Economic Code of Ukraine (Statements of the Verkhovna Rada of Ukraine (RT), 2003, № 19-20, № 21-22, p. 144. URL: https://zakon.rada.gov.ua/laws/show/436-15 (accessed 16 October 2020).

8. Melnik A.O. (2004) Ekonomicna adaptazia pidpriemstv u mehanizmi pidvischenya ih konkurentnozdatnodsti [Economic adaptation of enterprises in the mechanism of increasing their competitiveness]. Bulletin of the Technological University of Podillya, vol. 6, pp. 206-211.

9. Melnik A. O. (2004) Stanovlennja ta rozvytok ponjattja «adaptacija pidpryjemstva [Formation and development of the concept of "adaptation of an enterprise]. Bulletin of the University of Technology Podillya, vol. 2, no. 1, p. 135-138.

10. Denisenko M.P., Budiakova O.Y. (2018) Modern strategies for personnel management of enterprises. Priazovsky Economic Bulletin, no. 5(10), pp. 175-181. URL: http://pev.kpu.zp.ua/journals/2018/5_10_uk/32.pdf (accessed 16 October 2020).

11. Denisenko M.P., Budiakova O.Y. (2019) Suchasni strategiyi upravlinnya personalom v epohu cifrovoyi ekonomiki. Digital economy and digital society [Modern strategies personnel management in the epoch of the digital economy], p. 234-242.

12. Denisenko M.P., Budyakova O.Y. (2018) Kadrova polityka jak osnova formuvannja strateghiji upravlinnja personalom pidpryjemstv [Personnel policy as the basis for the formation of a strategy for personnel management of enterprises]. Learned notes of the University "KROK"(economic sciences), no. 4(52), pp. 231-238.

13. Denisenko M.P., Budiakova O.Y. (2019) Pidvyschennia indeksu liuds'koho kapitalu - vazhlyva skladova innovatsijnoi kadrovoi 
polityky pidpryiemstv [Enhancing human capital index - important complex of innovative personnel policy]. Economy and the state, vol. 4, pp. 11-17. DOI: 10.32702/2306-6806.2019.4.11

14. Denysenko M., Budiakova O., Shaposhnikova O. The essence and role of investment business planning in modern economic conditions. Learned notes of the University "KROK", vol. 1(53), pp. 46-50. DOI: https://doi.org/10.31732/2663-2209-2019-53-46-46-5012

15. Denisenko M., Budyakova O., Voloshchuk Y. (2019) Zarubizhniy dosvid upravlinnya personalom [Foreign experience of personnel management]. Academic notes of the University "KROK", vol. 2(54), pp. 137-144. DOI: https://doi.org/10.31732/2663-22092019-53-137-144

\section{Jimepamypa:}

1. Величко О.Г., Момот Ю.Г. Менеджмент зовнішньоекономічної діяльності: опорний конспект лекцій. Дніпропетровськ : НМетАУ, 2010. 52 c.

2. Гузенко Г.М., Гайдученко Ю.О. Зовнішньоекономічна діяльність підприємства: сутність, економічний механізм ії розбудови, особливості. Вісник Національного університету «Юридична академія України імені Ярослава Мурого. 2013. Вип. 3. С. 53.

3. Козак Ю.Г., Лонгвінова Н.С., Заєць М.А. Зовнішньоекономічна діяльність підприємств. Київ : «Освіта України», 2012. Вип. 4.

4. Мельник А.О. Світові економічні кризи в економіці України та їх наслідки. Глобальні та наиіональні проблеми економіки. 2014. Вип. 2. С. 108-113.

5. Мельник А.О. Адаптація вітчизняних підприємств в умовах світової економічної кризи. Бізнес-Інформ. 2012. № 10. С. 30-32.

6. Закон України про зовнішньоекономічну діяльність (Відомості Верховної Ради УРСР (ВВР), 1991, № 29, ст. 377). URL: https://zakon.rada.gov.ua/laws/show/959-12 (дата звернення: 15.08.2020)
7. Господарський кодекс України (Відомості Верховної Ради України (ВВP), 2003, № 18, № 19-20, № 21-22, ст. 144). URL: https:// zakon.rada.gov.ua/laws/show/436-15 (дата звернення: 16.10.2020).

8. Мельник А.О. Економічна адаптація підприємств у механізмі підвищення їх конкурентоздатності. Вісник Технологічного університету Поділля. 2004. № 6. С. 206-211.

9. Мельник А.О. Становлення та розвиток поняття «адаптація підприємства. Вісник технологічного університету Поділля. 2004. Ч. 2. Т. 2. № 1. С. 135-138.

10. Денисенко М.П., Будякова О.Ю. Сучасні стратегії управління персоналом підприємств. Приазовський економічний вісник. 2018. № 5(10). C. 175-181. URL: http://pev.kpu.zp.ua/ journals/2018/5 10 uk/32.pdf (дата звернення: 16.10.2020).

11. Mykola Denysenko, Olena Budiakova. Modern strategies personnel management in the epoch of the digital economy. Digital economy and digital society: Series of monographs Faculty of Architecture, Civil Engineering and Applied Arts Katowice School of Technology Monograph 22. Wydawnictwo Katowicach, 2019. C. 234-242.

12. Денисенко М.П., Будякова О.Ю. Кадрова політика як основа формування стратегії управління персоналом підприємств. Вчені записки Університету "КРОК" (економічні науки). № 4(52). 2018. С. 231-238.

13. Денисенко М.П., Будякова О.Ю. Підвищення індексу людського капіталу - важлива складова інноваційної кадрової політики підприємств. Економіка та держава. 2019. № 4. С. 11-17. DOI: 10.32702/2306-6806.2019.4.11

14. Denysenko M., Budiakova O., Shaposhnikova O. The essence and role of investment business planning in modern economic conditions. Вчені записки Університету «КРОК». Вип. 1(53). С. 46-50. DOI: https://doi.org/10.31732/2663-2209-2019-53-46-46-5012.1

15. Денисенко, М., Будякова, О., \& Волощук, Ю. (2019). Зарубіжний досвід управління персоналом. Вчені записки Універсиmemy «КРОК», № 2(54), C. 137-144. DOI: https://doi.org/10.3173 2/2663-2209-2019-53-137-144

Аннотация. В данной статье показано, что организация развития внешнеэкономической деятельности (ВЭД) на предприятии любой формы деятельности является одним из основных элементов, который помогает качественно наладить деятельность предприятия на внешних рынках. Доказан факт, что каждая интерпретация ВЭД является дополнением к предыдущим. Была исследована структура формирования ВЭД на предприятии. Рассмотрены основные ключевые элементы, позволяющие успешно реализовать ВЭД. Были проанализированы причины, заставляющие предпринимателей внедрять ВЭД. Также исследованы основные направления экономической деятельности во всех странах мира. Проведен анализ ВЭД, даны рекомендации по эффективности реализации и ведения внешнеэкономической деятельности. Вопрос ВЭД актуален и требует детального изучения.

Ключевые слова: внешнеэкономическая деятельность, экономика, прибыль, менеджмент, кадры, эффективность, ресурсы.

Анотація. У цій статті встановлено, що організація розвитку зовнішньоекономічної діяльності на підприємстві $\epsilon$ одним 3 основних елементів, який допомагає якісно налагодити діяльність підприємства на зовнішніх ринках. Актуальність зовнішньоекономічної діяльності пояснюється тим, що зовнішня економічна діяльність дає більше можливостей для отримання прибутку для будь-якого підприємства і створює умови для виходу на міжнародну арену і створення конкуренції для підприємств, які вже здобули ім`я на ринку. Успішне здійснення ЗЕД на підприємстві залежить від двох основних чинників: здатності підприємця успішно адаптуватися до зовнішніх чинників, міжнародного попиту, вчасно реагувати на зміни вимог споживачів та здатності власника підприємства успішно організувати структуру управління та контролю зовнішньоекономічної діяльності. Ці два елементи однаково важливі, особливо в нинішніх умовах розвитку людського потенціалу і світової економіки. Важливими особливостями зовнішньоекономічної діяльності є: використання сучасної виробничої системи, яка створить більш конкурентоспроможний продукт; чітке та конструктивне управління персоналом підприємства, застосування нових методів підбору персоналу, підбору найбільш кваліфікованих кадрів; створення творчих та інноваційних відділів, які відповідатимуть за впровадження новітніх технологій; розширення прав і можливостей відповідальних осіб; створення приємної та комфортної робочої атмосфери; впровадження ефективної системи розвитку кар'єри та системи мотивації персоналу; створення інноваційної корпоративної культури, спільне вирішення проблем з персоналом, що дасть більше можливостей для комплексного управління персоналом. Саме адаптивність управління персоналом є рушійним фактором ефективної реалізації зовнішньоекономічної діяльності, оскільки саме здатність адаптуватися до екологічних змін створює передумови для створення ефективної системи зовнішньоекономічної діяльності, яка повинна служити основним драйвером щодо забезпечення прибутковості підприємства в сучасному світі.

Ключові слова: зовнішньоекономічна діяльність, економіка, прибуток, менеджмент, кадри, ефективність, ресурси. 